\title{
TRAINING OF FINANCIAL GOVERNANCE FOR SMES MEMBERS OF BUSINESS GROUP OF VILLAGE RAWA KALONG, SINDUR MOUNTAIN INCREASE IN IMPROVING FINANCIAL PERFORMANCE
}

\author{
Desy Mariani $^{*}$, Suryani ${ }^{1}$, Yusi Sudariati Fajar ${ }^{1}$ \\ ${ }^{1}$ Departement of Accounting, Faculty of Economic and Business, Budi Luhur University \\ *desy.mariani@budiluhur.ac.id
}

\begin{abstract}
Micro, Small and Medium Enterprises (MSMEs) conducted in the home environment is one of the main sources of livelihood for residents in kalong rawa village, GunungSindurSubdistrict, Bogor, West Java.to conduct a business well of course required adequate resources such as working capital, the ability of human resources to manage its business and also the available of markets for resulting products. Skills and competence of human resources is the main factor of business continuity. How about limited working capital, a micro and small business should continue to survive. The ability to manage finance to keep the business running and meet the needs of everyday becomes a major problem in the management of micro and small businesses at home, especially when business man have problems in health,children's education or other problems that require more funds than their regular expenses. Another problems faced by business man are preparation of the cost structure and calculation of working capital because sometimes the result product must follow the store payment terms, this conditions often faced by business man. With the problem above, in this training is expected to help provide knowladge, open minded insight and improve the skills of business man to be more able to plan finance, more orderly in used of working capital so that is not eroded by household needs. So in the end can get the appropriate benefits and develop the business for the better.
\end{abstract}

Keywords: Small Business, Business Actor, Small Business Financial Management Training

\section{INTRODUCTION}

Micro, Small and Medium Enterprises (MSMEs) in Indonesia are one of the pillars of the Indonesian economy besides cooperatives. This can be seen from the concrete evidence that most MSMEs in Indonesia did not face a crisis amid the global crisis in 2008. The development of the number of MSMEs from year to year is increasing. the development of MSMEs is only seen in terms of numbers. In general, especially in the financial aspect, only a few MSMEs experienced growth in terms of financial performance. This cannot be separated from the lack of awareness of MSMEs on the importance of corporate financial management.

Financial management is an important aspect for the progress of the company. Financial management can be done through accounting. Accounting is a systematic process to produce financial information that can be used for decision making for its users. As long as MSMEs still use money as a exchange tool, accounting is needed by MSMEs. Accounting will provide several benefits for MSME players, including: (1) MSMEs can find out the company's financial performance, (2) MSMEs can find out, sort and distinguish company assets and owner's property, (3) MSMEs can find out the position of funds both sources and users , (4) MSMEs can make the right budget, (5) MSMEs can calculate taxes and (6) MSMEs can know the flow of cash for a certain period.

Seeing the benefits generated by accounting, MSME actors should be aware that accounting is important for their companies. The use of accounting can support the progress of MSMEs, especially in financial matters. Increased profits are increasing, the development of MSMEs will be better so that MSMEs will truly be one solution to the economic problems in Indonesia. However, there are still many MSMEs that have not used accounting to support their business. The reasons for SMEs not using 
accounting include accounting is considered difficult and unimportant. Some MSME players say that without accounting, the company continues to run smoothly and always earns profit.

\section{Problem}

Many MSME players feel that their company is running normally but actually these MSMEs have not experienced development. When they get questions about the profits earned each period, they cannot show a nominal number but with tangible assets such as land, houses and vehicles. Furthermore, these assets are obtained not only with company funds but sometimes coupled with personal assets. Such assets are sometimes also not used for companies but are used for personal gain and there is no recording or separation between the two. This causes the development of the company, especially in terms of financial performance can not be clearly known.

UMKM actors find it difficult to use accounting in their business activities. This is because there are no guidelines or books that can be used as references for learning to manage MSME finances. Book books circulating at this time do not yet have a focus on financial management of MSMEs. There are several accounting book titles for MSMEs, but look at the contents as well as accounting books for large companies. Many transactions occur in MSMEs such as barter / exchange services but are not given examples in the book so that when the transaction occurs, MSME players prefer not to record it. If there are many similar transactions and are not recorded, it will certainly have a negative impact on the company's financial performance. In addition to no books specifically discussing transactions in MSMEs, many MSMEs are reluctant to read books.

\section{Extensive Target}

The target chosen was the UMKM players who were members of the 20-person Rawa Kalong Village Business Group. This target setting is an effort to improve the financial performance of MSMEs that have been registered in government institutions so that their development can be easily known and monitored. Furthermore, it is hoped that training participants can pass on the knowledge gained to other UMKM players who are nearby.

\section{Problem Solving Method}

The main problem related to this problem is the unwillingness and inability of UMKM actors to use accounting in business activities to manage company finances. Therefore, the proposal for a more operational solution in this PKM activity is the first step is to motivate MSME actors to use accounting by first providing an overview and important role of accounting for MSMEs, the second step is to organize MSME accounting training as a whole, covering the stages of recording up to preparation the financial report for MSMEs in the third step of Rawa Kalong Village is to provide applications for the results of training at each UMKM accompanied by the PKM TEAM.

Table 1: Evaluation Design

\begin{tabular}{lll}
\hline \multicolumn{1}{c}{ Purpose } & \multicolumn{1}{c}{ Achievement indicator } & \multicolumn{1}{c}{ Benchmarks } \\
\hline $\begin{array}{l}\text { Participants are motivated to } \\
\text { use accounting. }\end{array}$ & $\begin{array}{l}\text { Participants want to use accounting in their } \\
\text { business activities. }\end{array}$ & $\begin{array}{l}\text { Participants who want to use } \\
\text { accounting raise their hands. }\end{array}$ \\
$\begin{array}{l}\text { Participants are able and } \\
\text { skilled in making financial } \\
\text { reports }\end{array}$ & $\begin{array}{l}\text { Participants are able and skilled in } \\
\text { journalizing, transferring, compiling lists of } \\
\text { balances, recording adjustments, compiling } \\
\text { lists of balances after adjustments, and } \\
\text { compiling financial statements. }\end{array}$ & $\begin{array}{l}\text { Participants have a journal } \\
\text { book, a list of balances along } \\
\text { with adjustments, and } \\
\text { financial statements. }\end{array}$ \\
& $\begin{array}{l}\text { Participants are able and skillful in making } \\
\text { their respective MSME financial } \\
\text { statements. }\end{array}$ & \\
$\begin{array}{l}\text { Participants apply accounting } \\
\text { in their respective MSMEs }\end{array}$ & & $\begin{array}{l}\text { There are financial reports in } \\
\text { each participant's MSME. }\end{array}$ \\
\hline
\end{tabular}




\section{RESULT AND DISCUSSION}

On the first day it went smoothly. The first material given is introduction or introduction to accounting. the speaker explained the importance of accounting for MSMEs. Most audiences do not understand the accounting function, even most trainees consider that accounting is a complicated, difficult, troublesome, time-consuming field. This first material is filled with strengthening the importance of accounting for small businesses (MSMEs).

In this session there was an interesting discussion between the audience and the speaker about the basic business concept. Some audiences have different perceptions about a business or entity. Based on the discussion of this entity concept, finally an understanding of the concept of the entity was finally obtained. After obtaining an agreement on the entity concept, continued with the financial reporting function for etity. After the one hour ISHOMA program, the program continued with the second material regarding MSME accounting transactions. In this session, each audience was asked to explain the operating activities of each of their businesses. Furthermore, economic activities and activities are identified. Based on the identification of activities, participants will find it easier to identify the costs incurred during the production process and then practice the calculation of production and income costs.

In the last session is to apply to excel calculation where in this application we will report all transactions into general cash books, expense books, accounts receivable books, purchase books, debt books, inventory books, income statements, changes in capital statements, and balance sheets.

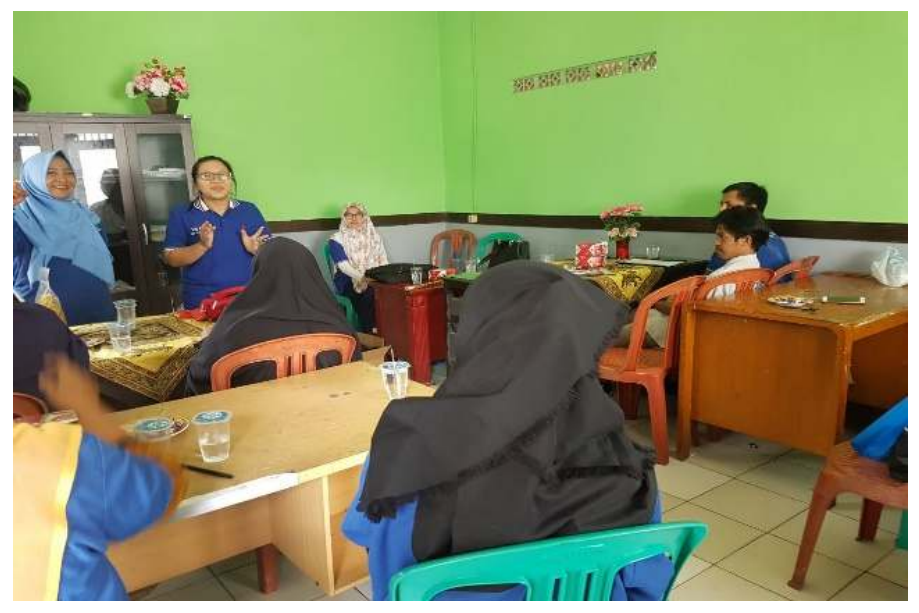

Figure 1:Community Service ProcessActivities

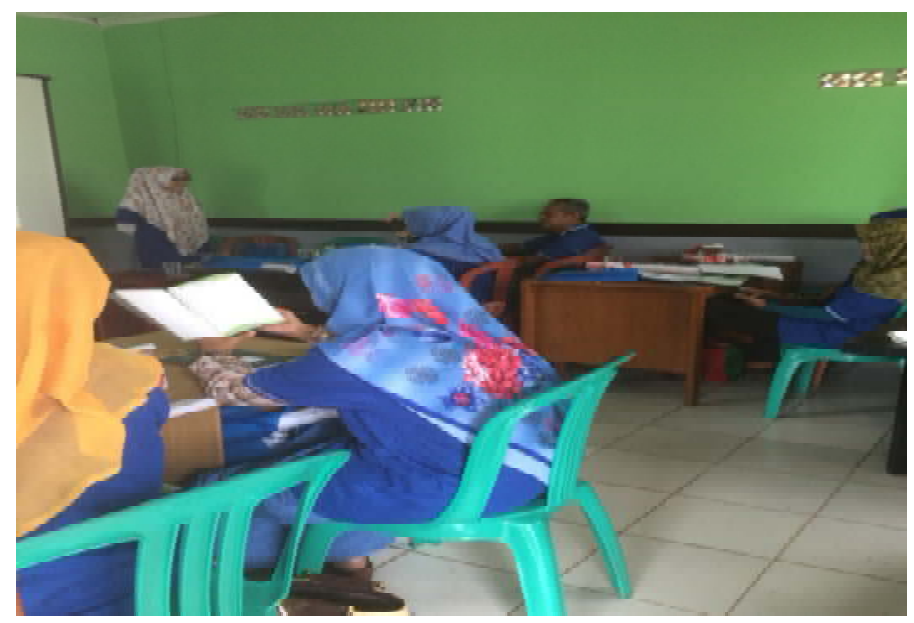

Figure 2: Process of Service Practicum 
After the presentation of the material the participants gave questions was presented as follows.

a. Is it important for MSME owners to know how to make simple financial statements?

b. The reason for the need to prepare financial statements for MSMEs?

c. When is the right time to start compiling a Financial Report?

d. How to prepare simple financial statements for MSMEs?

The Importance of Preparing Financial Reports for SMEs

a. Can find out, sort and differentiate business assets and owner's property

b. Can find out business performance and progress,

c. Can find out the source and use of existing funds,

d. Can make the right budget and business planning,

e. Can know the flow of cash during a certain period,

f. Can find out business profits or losses,

g. Can find out business prospects in the future

When to Start Preparing Financial Reports for SMEs

Ideally when deciding to start a business we must immediately separate personal finance from business finance. Doing records for each financial transaction related to the business in full and in detail, no matter how small the value. The goal is so that we can know for sure the development of the business that is carried out.

\section{Separating Business Finance With Personal Finance}

The negligence that is often done by many business owners is not to separate personal money and business money. When he made a lot of business money he consumed it excessively, so when the business needed capital, the money was spent on consumption costs.

Separating Personal and Business Money is Mandatory!

After Separating Personal and Business Money, Then Record every income and expenditure of money. At the end of the month do the businessprofit / loss calculation. Separate the budget for personal gain from the results of the business. For Recording of Cash Receipts must be separated Receipt from Business (Revenue), Receipt from Loans (Debt) and Receipt from Owner (Capital / Debt).

\section{CONCLUSION}

Dedication activities in the form of Financial Governance training for MSMEs in the Rawa Kalong Village organized by the Faculty of Economics and Business, Jakarta Budi Luhur University were able to make a positive contribution to improving the ability of financial governance for MSMEs in terms of identifying various forms of costs and making financial reports. Therefore, as a suggestion, similar activities need to be developed by inviting many participants from other MSMEs, so as to realize independent MSMEs as well as for financial governance training for SMEs who understand and apply good financial management as a provision for managing the business. The implementation of these activities must be carried out on an ongoing basis for SMEs to be achieved, while the University's needs for community service activities can be carried out properly.

\section{REFERENCES}

Ikatan Akuntan Indonesia. (2011). Standar Akuntansi Keuangan. Jakarta, Salemba Empat

Kieso, D. E. \& Jerry J. W. (2002). Akuntansi Intermediate. Jilid 3. Jakarta :Erlangga.

Warren, Carl S., James. R \& Philip E. Fees. (2006). Pengantar Akuntansi, Edisi Dua Puluh Satu, Jakarta: Salemba Empat

Warsono, Sony, Arif Darmawan, dan M. Arsyadi Ridha. (2010). Akuntansi UMKM Ternyata Mudah Dipahami dan Dipraktikkan. Asgard Chapter Yogyakarta 